\title{
An example of a constructivist blended learning environment for developing language skills: www.dinleizleanlat.com*
}

\author{
Aliye ERDEM ${ }^{* *}$ Mukaddes ERDEM $^{* * *}$ Ferhat Kadir PALA $^{* * * *}$
}

\begin{abstract}
The purpose of this research is to create a model of constructivist blended learning environment which will contribute to the development of listening and speaking skills, and which consists of faceto-face and online dimensions. The participants of the implementations for developing the blended learning environment are composed of 26 fourth graders - 12 girls and 14 boys - who attend a private elementary school in the academic year 2011-2012. The learning environment is evaluated based on the rate of using the learning environment by the participants and on their feedbacks. The developmental characteristics and interests of the fourth graders attending the elementary school where the model will be implemented are taken into consideration in developing the blended learning environment. Since the research is limited to the language skills of listening and speaking, the face-to-face and online learning environments are based on only these skills. The creation and development of the blended learning environment is presented under the subheadings of analysis, design, development, implementation and evaluation. As a result of the research which is conducted in the blended learning environment, it is concluded that the participants usually have shared sound recordings related to the theme "listen" most and the theme "tell" least among the themes "listen", "watch" and "tell"; that the participation in the implementation has decreased in time; and that the participants have been satisfied with studying in such an environment.
\end{abstract}

Keywords: Language skills, constructivist blended learning environment, listening and speaking skills.

\footnotetext{
* This study is a part of the PhD. dissertation conducted by the first author with the supervision of second author at Hacettepe University Institute of Social Sciences.

${ }^{* *}$ Dr. Ankara University, Faculty of Educational Sciences, Ankara, Turkey.

E-mail: aliye.erdem@ankara.edu.tr

*** Assoc. Prof. Dr., Hacettepe University, Computer Education and Instructional Technology, Ankara, Turkey. E-mail: erdem@hacettepe.edu.tr

${ }^{* * * *}$ Res. Assist., Hacettepe University, Computer Education and Instructional Technology, Ankara, Turkey. E-mail: fkpala@gmail.com
} 


\section{SUMMARY}

Purpose and Significance: The purpose of this research is to create a model of constructivist blended learning environment which will contribute to the development of listening and speaking skills, and which consists of face-to-face and online dimensions. The blended learning environment has been developed based on the acknowledgment that it is necessary to blend the Internet, which is a part of pupils' daily lives, with deliberate learning processes so as to promote motivation and learning. The learning environment has also been developed based on the constructivist approach in accordance with the view that the learning environment should be composed of activities which encourage pupils to be active in learning, to think, to question, to solve problems, to cooperate and to hold responsibilities in order to ensure a meaningful and permanent learning.

Method: The steps (analysis, design, development, implementation and evaluation) of the development process for an instructional design have generally been followed in the development of the constructivist blended learning environment. The participants of the research are 26 fourth graders - 12 girls and 14 boys - who attend a private elementary school in the academic year 2011-2012.

Development Process of the Constructivist Blended Learning Environment: The blended learning environment consists of online and face-to-face dimensions, and it has been developed based on constructivist principles. The learning environment has been designed in pursuit of the literature review about blended learning environments, the constructivist approach, basic language skills and the characteristics of the target group, and it has been adjusted according to the expert opinions. Then the content and teaching materials have been developed according to the developmental characteristics and interests of the target group, and they have been put into implementation.

The website is designed to look like a book and the picture of a bookworm is used as the avatar. Tools for using the environment are represented with symbols so as to ensure that the participants understand them easily and they encounter with written texts as seldom as possible. The themes "Listen, Watch, Tell" are used in each lesson in order to reflect the purpose of the learning environment. Pupils have commented via sound recordings or video recordings optionally during the activities in the online learning environment. Each lesson is designed within the framework of the themes concerning the skills to be developed, and each theme is related with 
the relevant teaching materials and tasks. It is aimed to achieve a contentrich learning environment by use of various types such as animations, stories and poems. Self-assessment questions are added to each activity in the online learning environment.

In the face-to-face learning environment, activities have been carried out to complement those shared or to be shared in the online learning environment.

The implementation is organized in a way to ensure that face-to-face and online activities complement each other, and it is conducted by the researcher. The researcher has taken the activities to the classroom; studied with the pupils; introduced them with the activities; and carried out some rewarding activities to motivate the pupils.

The evaluation of the environment has been carried out for blended and face-to-face dimensions separately. The evaluation data about the online dimension of the blended learning environment has been obtained through examining the online logs revealing the rate of using the environment by the pupils, and the data about the face-to-face dimension has been obtained via teacher observations.

Conclusions: The online dimension of the blended learning environment could not be used as expected. While the pupils have been more interested in the first activities uploaded to the learning environment, it is seen that the level of participation has decreased in time. The pupils have preferred to comment via sound recordings instead of videos, and shared sound recordings related to the theme "Listen" most and the theme "Tell" least.

Although the pupils have not used the online learning environment frequently, it is determined that the activities in the online learning environment have attracted their attention, aroused their curiosity and made them enjoy the activities. The following examples of pupil comments can support this view:

"It was a very funny video. I continued to laugh even after watching it. I laughed while watching it."

"I am happy that this website is built. Thanks to it, I can now think of a better profession for the future."

It can be said that the level of participation in both individual and group activities is high in the face-to-face dimension of the blended learning environment. Pupils have made the necessary preparations with a high level of motivation, participated in the discussions, answered the questions, and participated in the activities in the face-to-face learning environment. 


\title{
Dil Becerilerinin Geliştirilmesi için Yapılandırmacı Karma Öğrenme Ortamı Örneği: www.dinleizleanlat.com*
}

\author{
Aliye ERDEM $^{* *} \quad$ Mukaddes ERDEM $^{* * *} \quad$ Ferhat Kadir PALA $^{* * * *}$
}

ÖZ. Bu çalışma, dinleme ve konuşma becerilerinin geliştirilmesine katkı sağlayacak, yüz yüze ve çevrim içi boyutları olan bir yapılandırmacı karma öğrenme ortamı modeli oluşturmak amacıyla gerçekleştirilmiştir. Karma öğrenme ortamını geliştirme uygulamalarına, 2011 - 2012 öğretim y1lında özel bir ilköğretim okuluna devam eden bir şubedeki 12 kız, 14 erkek öğrenci olmak üzere toplam 26 dördüncü sınıf öğrencisi katılmıştır. Öğrenme ortamı, araştırmaya katılan öğrencilerin ortamı kullanım oranı ve geri bildirimlerine dayalı olarak değerlendirilmiştir. Karma öğrenme ortamı oluşturulurken, bu modelin uygulanacağ öğrencilerinin gelişim özellikleri ve ilgi alanları dikkate alınmıştır. Çalışma, dil becerilerinden yalnızca dinleme ve konuşma becerileri ile sınırlandırıldığından yüz yüze ve çevrim içi öğrenme ortamları yalnızca bu beceriler üzerine yapılandırılmaya çalışılmıştır. Karma öğrenme ortamının oluşturulması ve geliştirilmesi; analiz, tasarım, geliştirme, uygulama ve değerlendirme alt başlıkları altında sunulmuştur. Karma öğrenme ortamında gerçekleştirilen bu çalışma sonunda öğrencilerin dinle, izle anlat temalarından en fazla dinle, en az anlat temasında olmak üzere çoğunlukla ses kaydı ile paylaşım yaptığı, uygulamanın başındaki katılımın ilerleyen zamanda azaldığı, öğrencilerin böyle bir ortamda çalışmaktan memnun kaldığı sonuçları elde edilmiştir.

Anahtar Sözcükler: Dil becerileri, yapılandırmacı karma öğrenme ortamı, dinleme ve konuşma becerileri.

\footnotetext{
* Bu çalışma Hacettepe Üniversitesi Sosyal Bilimler Enstitüsü’nde, ikinci yazarın danışmanlığında birinci yazar tarafından gerçekleştirilen doktora tezinin bir bölümünden oluşmaktadır.

** Dr. Ankara Üniversitesi Eğitim Bilimleri Fakültesi Ankara, Türkiye. E-posta: aliye.erdem@ankara.edu.tr

${ }^{* * *}$ Doç. Dr., Hacettepe Üniversitesi Bilgisayar ve Öğretim Teknolojileri Eğitimi Anabilim Dalı, Ankara, Türkiye. E-posta: erdemm@hacettepe.edu.tr

**** Arş. Gör., Hacettepe Üniversitesi Bilgisayar ve Öğretim Teknolojileri Eğitimi Anabilim Dal, Ankara, Türkiye. E-posta: fkpala@gmail.com
} 


\section{GíRiș}

Dil öğretiminde genel olarak bireylere doğru, açık ve etkili bir iletişimi gerçekleştirebilecek dilsel becerileri kazandırma; onların düşünme güçlerini geliştirme, yetkinleştirme ve toplumsallaştırma süreçlerine katkıda bulunma gibi özellikler temel alınmaktadır. Anadili öğretimi sürecinin en genel amacı ise öğrencilerin anlama ve anlatma becerilerinin geliştirilmesidir (Sever, Kaya ve Aslan, 2006:13). Bu genel amaca ulaşmada dilsel beceriler olarak da adlandırılan dilin temel etkinlik alanlarında bireyin kendini geliştirmesi önemli görülmektedir. Temel dil becerileri olarak adlandırılan bu beceriler; dinleme, konuşma, okuma ve yazma olarak adlandırılır. Bu becerilerin geliştirilmesinde, okul dönemindeki öğretme-öğrenme süreçleri ve bu süreçlerdeki etkinliklerin önemli bir yeri vardır.

Öğretme ve öğrenme etkinlikleri, eğitimin temel öğeleri arasında yer almaktadır. Eğitim amaçlarının gerçekleşmesinde öğretme-öğrenme süreçlerinin etkililiği ise büyük ölçüde öğretmene ve onun öğretme ortamında kullandığı her türlü materyal ile uygulamış olduğu yöntemlere bağlıdır. İnsan hayatındaki en önemli süreçlerden biri olan eğitim, günümüzün gereksinimlerine yanıt verebilmek için gelişen teknolojinin olanaklarını kullanmak durumundadır. Öyle ki öğrenme, yalnızca sınıfla sınırlı kalmamakta; sınıftaki yüz yüze öğrenme ortamları çevrim içi öğrenme ortamlarıyla bütünleştirilerek sınıf dışına tanınabilmektedir. Yüz yüze ve çevrim içi ortamların bütünleşmesiyle oluşan bu türden öğrenme ortamları ise karma öğrenme ortamları olarak adlandırılmaktadır.

\section{Karma Öğrenme Ortamı}

Uluslararası alanyazında "blended", "hybrid" ya da "mixed"; Türkçe alanyazında ise "harmanlanmış" ya da "karma" öğrenme olarak adlandırılan bu öğrenme ortamı; yüz yüze öğrenme ile elektronik ya da uzaktan öğrenmeyi bütünleştirme, farklı öğrenme kuramlarını, yöntem ve tekniklerini birlikte kullanma, sınıftaki öğrenme sürecini çeşitli çevrim içi teknolojiler ile destekleme şeklinde tanımlanmaktadır (Brown, 2001; Driscoll, 2002; Mantyla, 2001; Osguthorpe ve Graham, 2003; Singh, 2002; Young, 2002;). $\mathrm{Bu}$ ortamları doğru zamanda, doğru yerde, doğru içerikle ve doğru öğretim yöntemiyle sunmak, öğrencilerin bu ortamlardan verimli şekilde yararlanmasını sağlayacaktır.

Farklı paylaşım yöntemleri ve öğrenme stillerini birleştiren bir öğrenme yaklaşımı olarak da tanımlanan karma öğrenme, öğrencilerin etkili ve verimli şekilde öğrenmesine yardımcı olur (Wu, Tennyson ve Hsia, 2010). Karma öğrenme ortamında öğrenenler belirli bir takvim çerçevesinde 
düzenli olarak ya da aralıklarla yüz yüze derslere devam ederken, sınıf dışında da çevrim içi olarak sunulan öğrenme materyalleri ile desteklenirler (Dabbagh ve Banan-Ritland, 2005:23).

Karma öğrenmede, çevrim içi eğitimin güçlü yönleri, yüz yüze eğitimin güçlü yönleri ile tamamlanır. Bu nedenle karma öğrenme ortamının amacı, çevrim içi erişim ile yüz yüze etkileşim arasında uyumlu bir dengeyi kurmaktır (Osguthorpe ve Graham, 2003). Bazı derslerin öğretim hedefleri, öğrenen özellikleri, bilgi ve beceri düzeyi ve öğretmenin tercihleri gibi etkenlerden dolayı yüz yüze ve çevrim içi öğrenme ortamlarında kurulacak etkileşim ya da uygulanacak stratejiler farklılık gösterebilir. Bütün bu farklı uygulamalardaki amaç, öğrencinin yüz yüze ve çevrim içi ortamlardan en iyi şekilde yararlanması, en verimli ve en etkili şekilde öğrenmesini sağlamaktır.

Karma öğrenme sürecinde öğretmen konu ile ilgili materyalleri çevrim içi ortama yükler. Bunlar; metin, ses, video, animasyon vb. olabilir. Böylece bilgi farklı yollarla öğrenciye ulaşır. Bunun yanında öğrenciler bu ortamda istedikleri materyalden yararlanabildikleri gibi, konu ile ilgili ödev, rapor gibi dosyaları da ortama yükleyebilirler. Öğrenciler ortamda bulunan eposta, çevrim içi sohbet alanları, forum gibi araçlar sayesinde aynı ya da farklı zamanlarda öğretmenleri ve arkadaşlarıyla iletişim kurarlar. Öğrenme, sadece sınıf ortamında kalmayıp, zaman ve mekândan bağımsız olarak sınıf dışında da devam eder. Kısaca karma öğrenmede, belirlenen beceriler kişiye kazandırılırken bireysel öğrenme yolları ve öğrenme teknolojileri kullanılarak yüksek başarının elde edilmesine odaklanılır (Ünsal, 2007; Wu, Tennyson ve Hsia, 2010). Yüz yüze ve çevrim içi ortamın bütünleştirilmesiyle oluşturulan karma öğrenme ortamının "ortam, etkinlik ve uygulamalar" boyutlarındaki özellikleri Tablo 1'deki gibi özetlenebilir.

Tablo 1. Karma ögrenme ortamı modeli (Eunjoo, 2006)

\begin{tabular}{|c|c|c|c|c|c|}
\hline \multicolumn{6}{|c|}{ Karma Öğrenme Ortamı } \\
\hline \multicolumn{3}{|c|}{ Yüz yüze öğrenme ortamı } & \multicolumn{3}{|c|}{ Çevrim içi öğrenme ortamı } \\
\hline Ortam & Etkinlikler & Uygulamalar & Ortam & Etkinlikler & Uygulamalar \\
\hline 1.Sinıf & 1.Sunuş & Siniflara & 1.Bilgisayar & 1.Sunuş & 1.Ders denetim \\
\hline 2.Eş & 2.Sunumlar & göre & tabanlı çevrim & 2. Alıştırma & araçları \\
\hline zamanlı & 3.Grup & değişiklik & içi öğrenme & 3.Bireysel çalışma & 2. Video \\
\hline 3. Çift & çalışması & gösterir. & 2.Eşzamanlı & 4. Tartışma & 3.İşitsel \\
\hline yönlü & 4. Alıştırmalar & & 3.Eşzamansız & 5. Ödev & 4.Sunum araçları \\
\hline iletişim & 5.Değerlendirme & & $\begin{array}{l}\text { 4.Tek yönlü } \\
\text { iletisim }\end{array}$ & $\begin{array}{l}\text { 6.Grup çalışması } \\
\text { 7.Benzetim }\end{array}$ & $\begin{array}{l}\text { (Powerpoint, } \\
\text { flash vb.) }\end{array}$ \\
\hline & & & $\begin{array}{l}\text { 5.Çift yönlü } \\
\text { iletişim }\end{array}$ & 8.Değerlendirme & 5.İletişim araçları \\
\hline
\end{tabular}


Tablo 1'de görüldüğü gibi karma öğrenme ortamlar1 farklı öğrenme ortamlarının olanaklarını kullanmayı sağlayan, etkileşim biçim ve seçeneklerini artırarak eğitimin çoktandır farkına vardığı bireysel farklılıklar ilkesini hayata geçirmeyi kolaylaştıran öğrenme ortamları olarak ortaya çıkmaktadır. O halde bu ortamların yapılandırmacı ilkeler üzerine yapılandırılması gerektiği söylenebilir.

\section{Yapılandırmacı Yaklaşım}

Bilginin doğası ile insanların nasıl öğrendiğinin açıklanmasına firsat veren bir öğrenme ya da anlam oluşturma teorisi (Abdal-Haqq, 1998) olan yapılandırmacı yaklaşıma göre bilgi, sıralardaki öğrencilere masa başındaki öğretmen tarafından aktarılamaz (Gray, 1997). Dış dünyadan gelen bilgiler zihin süzgecinden geçer. Herkesin dış dünya algısı ve bilgisi farklılık gösterdiğinden (Jonassen, 1999:139) anlamlı bir öğrenme, öğrencinin anlamı aktif olarak yapılandırmasıyla oluşur (Hanley, 1994; So, 2002).

Yapılandırmacı yaklaşımda öğrenme, nesnel gerçekliğin özümsenmesine dayanır ve eğitimin amacı, öğrencilere gerçek dünyanın kavranması konusunda yardım etmektir. Yapılandırmacılıkta bütün çaba, öğrenmenin kalıcılığının sağlamasına ve üst düzey bilişsel becerilerin oluşturulmasına katkı getirmektir (Şahin, 2001). Kişi daha önce bilmediği bir durumu anlamlandırmak için sadece var olan bilgilerini kullanabilir ve yeni öğrenmeler, diş dünyayla etkileşim sayesinde önceki bilgilerin üzerine kurulur. Öğrenenlere dünya hakkında bilgi verilir, bu içerik ve yapıyı kendi düşüncelerine yerleştirmeleri beklenir (Jonassen, 1991:28). Her ne kadar anlam oluşturma süreci bireysel olsa da etkileşim ortamındaki bağlamdan ayrı düşünülmez. Yapılandırmacıllğa göre hem kendisinin hem de grup arkadaşlarının öğrenmesi için birey öğrenme etkinliklerinde aktif olmalıdır. $\mathrm{Bu}$ nedenle öğrenme deneysel, öznel ve bireyseldir (Kaptan ve Korkmaz, 2001:41).

Yapılandırmacı öğrenme ortamlarında öğrenci merkeze alınmalı ve öğrencinin problem çözmesine firsat verilmelidir. Çünkü öğrenecek olan öğrencinin kendisidir. İçerik, bunu sağlayacak biçimde ve çok çeşitli olarak sunulmalıdır. Onun bu içeriği kendi öğrenme stratejisine göre düzenlenmesine olanak sağlanmalıdır. Yapılandırmacılıkta önemli olan, bilgiyi edinmekten ziyade bilginin yapılandırılma süreci; diğer bir deyişle öğrenmeyi öğrenmektir. Öğrencilerin bilgiyi yapılandırması sağlandığında, onlar kendileri için uygun öğrenme yöntemleri ve problem çözme stratejilerini geliştirirler (Arkün ve Aşkar, 2010).

Yapılandırmacı sınıfta hem ögretmen hem de öğrenciler bilgiyi, doğrudan ezberlenmesi gereken değişmez kalıplar olarak değil, içinde 
yaşanılan dünyaya ait dinamik, sürekli değişen bir bakış açısı ve bu bakış açısını genişletme becerisi olarak görürler. Yapılandırmacı anlayışın uygulandığ 1 öğrenme ortamları, bireylerin öğrenme sürecinde daha fazla sorumluluk almalarını ve etkin olmalarını gerektirir. Konular öğrencilerin önceki deneyimlerini dikkate alarak belirlenir. Böylece bireyler, zihinlerinde daha önce yapılandırdıkları bilgilerin doğruluğunu sınama, yanlışlarını düzeltme ve hatta önceki bilgilerinden vazgeçerek yerine yenilerini koyma firsatı elde ederler (Yaşar, 1998:71). Bütün bu etkinlikler uygulanırken öğrenciler kendi öğrenme süreçlerinde etkin olur. Yapılandırmacı yaklaşıma göre bilgi birey tarafindan yapılandırıldığından ortamda etkin olması gereken öğrenendir (Baki ve Bell, 1997). Öğrenilenlerle ilgili zihinsel yapılandırmalar, bireyin bizzat kendisi tarafından gerçekleştirilir. $\mathrm{Bu}$ nedenle, yapılandırmacı öğrenme ortamları, bireylerin çevreleriyle daha fazla etkileşimde bulunmalarına; dolayısıyla, zengin öğrenme yaşantıları geçirmelerine olanak sağlayacak biçimde düzenlenir. Video, bilgisayar, fotoğraf ve ses gibi diğer iletişim yollarıyla oluşturulan ortamlar öğrenciyi kendini farklı yollarla ifade etme konusunda da cesaretlendirir (Arkün ve Aşkar, 2010).

Yapılandırmacı öğrenme ortamlarında bilgi; gerçek yaşamdaki kullanımı yansıtan bir bağlam içinde sunulmalı, diğer bir söyleyişle yaşamla ilgili olmalı ve probleme dayalı olmalıdır (Herrington ve Standen, 2000). Çünkü insan yaşamın içindedir ve zihnini geliştirmek zorundadır. Öğrenenler edindikleri bilgilerin gerçek hayattaki yerini ayırt ederek bu bilgilerin kullanılacağ 1 ortamı görmelidir. Bilginin kazanılmasından çok yapılandırılması önemli olduğundan, öğrenilenlerin gerçek hayata aktarılarak paylaşılması daha anlamlı ve yararlı olacaktır. Jonassen (1999), yapılandırmacı öğrenme ortamlarında amaçlı ve anlamlı gerçek problemler üstünde durulması gerektiğini vurgulamıştır (Jonassen 1999; Jonassen, Peck ve Wilson 1999; Arkün ve Erdem, 2007). Gerçek hayatta karşılaşılan problemlerin ise genelde tek bir çözümü yoktur. Gerçek hayatta farklı problemlerle karşılaşan öğrenciler, farklı bakış açılarından bakma, değişik yollardan çözüme ulaşma konularında cesaretlendirilmelidir.

Öğrenme gelişmenin sonucu değil, gelişmenin kendisidir (Jonassen, Peck ve Wilson, 1999); bu nedenle ölçülmesi gereken yalnız sonuç değil aynı zamanda süreçtir. Bu bağlamda; değerlendirme öğretim sürecinden ayrı değil, öğretim ile birlikte yapılmalıdır. Yapılandırmacı öğrenme ortamlarında öğrenci çok boyutlu değerlendirilir. Yalnız ürüne değil; performansına, gelişimine, öğrenme-öğretme surecinde yaptıklarına, çevresiyle ve arkadaşlarıyla olan ilişkilerine bakarak değerlendirme yapılır. Yani değerlendirme, öğrenme sürecinin içinde yapılır (Brooks ve Brooks, 1993). 
Görülmektedir ki, anlamlı ve kalıcı öğrenmenin gerçekleşebilmesi için öğrenme ortamlarının öğrenciyi harekete geçiren, düşünmeye, sorgulamaya, araştırmaya, kendi bilgisini oluşturmaya ve oluşturduğu bilgiyi kullanmaya, problem çözmeye, işbirliği yapmaya ve sorumluluk üstlenmeye yönlendiren etkinlikleri içermesi gerekmektedir. Bütün bu görüşleri savunan yapılandırmacı yaklaşım, eğitimi tüm boyutlarıyla etkilemiştir ve öğrenme ortamlarının yapılandırmacı yaklaşıma uygun nitelik taşıması kaçınılmaz hale gelmiştir. $\mathrm{Bu}$ çerçevede bu çalışmada, dinleme ve konuşma becerilerinin geliştirilmesine katkı sağlayacak, yüz yüze ve çevrim içi öğrenme boyutları olan yapılandırmacı bir karma öğrenme ortamının oluşturulması ve geliştirilmesi amaçlanmıştır. Çalışmada karma öğrenme ortamının oluşturulması ve geliştirilmesi süreci öğrencilerin uygulamalara katılımıyla gerçekleştirilmiş, ortamın etkililiği öğrencilerden uygulama sürecinde elde edilen geribildirimlere dayalı olarak sınanmıştır. Çalışmanın yöntemi ve analiz aşamasından değerlendirme aşamasına kadar gerçekleştirilen süreç izleyen bölümlerde verilmiştir.

\section{YÖNTEM}

Öğrencilerin günlük yaşamlarının bir parçası olan internetin kasıtlı öğrenme süreçleri ile bütünleştirilmesinin motivasyon ve öğrenme açısından gerekli olduğu kabulünden hareketle bu çalışmada bir yapılandırmacı karma öğrenme ortamı modeli geliştirilmiş ve genel olarak öğretim tasarımı geliştirme sürecinin basamakları (analiz, tasarım, geliştirme, uygulama ve değerlendirme) izlenmiştir.

\section{Çalışma Grubu}

Araştırmanın çalışma grubunu 2011 - 2012 öğretim yılında özel bir ilköğretim okuluna devam eden bir şubedeki 12 kız, 14 erkek öğrenci olmak üzere toplam 26 dördüncü sınıf öğrencisi oluşturmuştur.

Çalışma, okulun araştırmaya yaklaşımı, olanakları ve öğrencilerin çevrim içi ortamlarla tanışıklık düzeyleri gibi özellikler dikkate alınarak özel bir ilköğretim okulunda gerçekleştirilmiştir. Ayrıca ilkokulun ilk üç yılında okuma yazma becerilerini geliştirmiş olan öğrencilerin temel dil becerileri üzerinde çalışabilecekleri kabulüyle araştırmanın dördüncü sınıf düzeyinde yürütülmesine karar verilmiştir.

\section{Verilerin Toplanması ve Analizi}

Karma öğrenme ortamının çevrim içi boyutuna ilişkin veriler, ortamın ögrenciler tarafından kullanım durumunu gösteren çevrim içi ortam kayıt 
raporları incelenerek; yüz yüze boyutuna ilişkin verilerse öğretmen gözlemleri yoluyla elde edilmiştir. Çevrim içi ortam kayıt raporları incelenerek çevrim içi ortama yüklenen her temadaki etkinliklerde öğrencilerin paylaşım sayısı belirlenmiştir. $\mathrm{Bu}$ veriler ve öğrencilerin süreçteki geri bildirimlerine dayalı olarak ortam geliştirilmiş ve değerlendirilmiştir. Ayrıca çevrim içi ortamda öğrencilerin sesli ya da görüntülü olarak belirttikleri ifadeler ortamın değerlendirilmesinde veri olarak kullanılmıştır.

\section{Yapılandırmacı Karma Öğrenme Ortamı Geliştirme Süreci}

Karma öğrenme ortamı çevrim içi ve yüz yüze boyutları bulunan bir öğrenme ortamıdır. Çalışmada öncelikle bu boyutları taşıyan karma öğrenme ortamı düzenlenmiştir. Yapılandırmacı yaklaşıma göre öğrenenin anlamı yapılandırması temel alındığından öğrenme ortamları, bireylerin çevreleriyle daha fazla etkileşimde bulunmalarına ve zengin öğrenme yaşantıları geçirmelerine olanak sağlayacak biçimde düzenlenmelidir. Bu çerçevede bu çalışmada oluşturulan karma öğrenme ortamı aşağıdaki yapılandırmacı ilkelere göre düzenlenmeye çalış1lmıştır.

Yapılandırmacı bir öğrenme ortamı;

- öğrenen etkinlik ve yönlendirmesine açık olmalı (aktif / yönlendirici),

- bireyin yapılandırmacı doğasını dikkate almalı (yapılandırmacı),

- işbirlikli çalışmaları ve öğrenenler arası sözel paylaşımları desteklemeli (işbirliği ve iletişim),

- bireyi kendi süreçleri üzerinde düşünmeye ve bunları ifade etmeye teşvik etmeli (yansitıcı),

- gerçeğin karmaşık doğasını hesaba katmalı (kompleks),

- amaçlı ve anlamlı gerçek problemler üstünde durmalıdır (amaçlı ve bağlamsal) (Jonassen, 1999; Arkün ve Erdem, 2007).

Karma öğrenme ortamının çevrim içi ve yüz yüze boyutları oluşturulurken öncelikle analiz çalışmaları, ardından da tasarım çalışmaları yürütülmüştür. Ortamın her iki boyutuna ilişkin geliştirme süreçleri aşağıda verilmişstir. 


\section{Çevrim içi öğrenme ortamının oluş̧urulması (www.dinleizleanlat.com)}

Çevrim içi ortam, araştırmacılar tarafından, yukarıdaki yapılandırmacı öğrenme ortamı ilkeleri gözetilerek ve büyük ölçüde öğrencilerin etkileşim içinde kendi öğrenmelerini yönetmeleri esasına dayalı olarak oluşturulmuştur. "www.dinleizleanlat.com" adresli çevrim içi ortamın oluşturulmasında ilk olarak analiz çalışması yapılmıştır.

\section{Analiz Çalışması}

Analiz çalışmaları, dinleme ve konuşma becerilerinin geliştirilmesi için gerekli ortamların belirlenmesine ilişkin alanyazın incelemeleriyle başlamıştır. $\mathrm{Bu}$ incelemeler, dil becerilerinin birbirinden bağımsız kazandırılması ve ölçülmesine, dolayısıyla öğrenenlerin öğrenme yetersizliklerini gidermede etkili yöntemler belirlemeye ilişkin güçlükler olduğunu göstermiştir. Buradan hareketle öğrencilerin hem bireysel hem işbirlikli çalışmalar yapabilecekleri, diğer becerilerden bağımsız olarak yalnızca dinleme ya da konuşma etkinliği gerçekleştirebilecekleri bir ortam gereksinimi ortaya çıkmıştır. Bu ortam çevrim içi olarak tanımlanmış ve geliştirilmiştir.

Dinleme ve konuşma becerilerinin ilkokul dördüncü sınıf düzeyinde geliştirilmesine karar verildikten sonra bu sınıf düzeyinde öğrencilerinin gelişim özellikleri incelenmiştir. Bu sınıf düzeyindeki çocukların ilgi duydukları konular, çizgi film kahramanları, şiirler, şarkılar, görseller vb. araştırılmıştır. İlkokul dördüncü sınıf Türkçe öğretim programı incelenmiştir.

Çevrimiçi öğrenme ortamında gerçekleştirilecek çalışma için uygulama yapılacak okulun ve öğrencilerin hangi olanaklara sahip olması gerektiği belirlenmiştir; örneğin, sınıflarda internet erişiminin olması, öğrencilerin evde bilgisayar ve internet ile çalışma ortamına sahip olması, okulda daha önce çevrim içi ortam ile ilgili uygulamaların yapılmış olması gibi. $\mathrm{Bu}$ özelliklerin belirlenmesi sonunda, çalışmanın bir özel okulda uygulanmasına karar verilmiştir. Uygulama yapılacak okul ile sınıf belirlenmiş ve okulda izlenen öğretim programı ile öğretmenin planları incelenmiştir. Çevrim içi ortamın geliştirilme çalışmaları tasarım ile devam etmiştir.

\section{Tasarım ve Geliștirme}

Çevrim içi ortamın tasarımı ve geliştirilmesi, ara yüz tasarımı ve içerik tasarımı olmak üzere iki boyutta ele alınmıştır. Yüz yüze öğrenme ortamının tasarım ve geliştirilmesinde ise yüz yüze öğrenme ortamının oluşturulması süreci açıklanmıştır. 


\section{a) Çevrimiçi ortam ara yüz tasarımı}

Öğrenciler için önemli bir öğrenme aracı olması nedeniyle ve öğrencilerin okul yaşantılarının bir parçası olan ders kitaplarıyla bütünlük sağlamak amacıyla web sitesi kitap görüntüsü üzerinde tasarlanmıştır. Böylece web sitesi görünümünün öğrenciler için anlamlı ve somut olarak algılanması sağlanırken aynı zamanda dersleriyle ilişkili olduğu izlenimi güçlendirilmiştir. Web sitesindeki kitap görüntüsünün koyu mavi renkteki bir fon üzerinde açık renkte gösterimine karar verilmiş; böylece kitap görüntüsünün seçiciliği, algılanması ve ayırt ediciliği artırılmaya çalışılmıştır.

Çevrim içi öğrenme ortamına giriş ekranında; öğrencileri karşılayan "Merhaba, hoşgeldiniz." yazısı, öğrencilerin kullanıcı adı ve parolasını yazarak siteye giriş yapabileceği bir bölüm ve siteye giriş yapmak için dolduracağı formu açan bir bağlantı bulunmaktadır (Şekil 1). Ortamın giriş ekranından itibaren bütün bölümlerindeki yazılar “Comic Sans” yazı tipiyle verilmiştir.

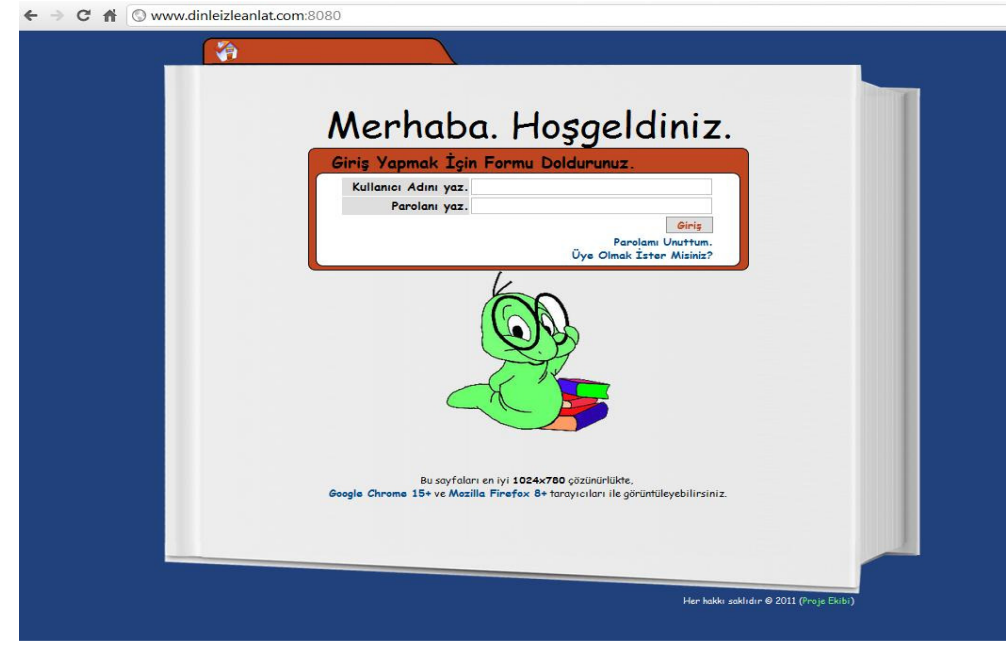

Şekil 1. Çevrim içi öğrenme ortamına giriş sayfasının ekran görünümü

Çevrim içi öğrenme ortamının giriş ekranında, sitenin diğer bölümlerde de kullanılan kitap kurdu resmi görülmektedir (Şekil 1). Hem ortam tasarımındaki kitap görüntüsü ile ilişkili olması hem de öğrenciler için sevimli bir resim olmas1 nedeniyle avatar olarak kitap kurdunun kullanılmasına karar verilmiştir. Kitap kurdu avatarının, ortamın giriş ekranından itibaren bütün bölümlerde kullanılmasıyla öğrencilerin olumlu 
bir yaklaşımla ilgisini çekerek onları güdülemeye ve çevrim içi öğrenme ortamının yapısındaki bütünlük hissettirilmeye çalışılmıştır.

Çevrim içi öğrenme ortamına üye olduktan sonra kullanıcı adı ve parola yazılarak ortama girildiğinde ana sayfaya erișilmektedir. Ana sayfadaki kitap görüntüsünün să̆ tarafinda, kitap ayract şeklinde düzenlenmiş ders adları bulunmaktadır (Şekil 2). Ders adları kitap ayraçları üzerinde verilerek ortam tasarımıla uyumlu bir yap1 oluşturulmaya ve sitenin, öğrencilerin kendi yaşamlarındaki bütün dersleri kapsayacak nitelikte olduğu anlamı verilmeye çalışılmıştır. Derslerin, bir bütün içindeki farklı parçalar olarak düşünülmesinin sağlanması ve öğrencilerin ilgisini çekmesi amaciyla her ders farklı renklerle gösterilmiştir. Ayrıca çevrim içi ortamdaki dersler, ilköğretim programındaki adlarıyla değil, öğrencileri motive edici ve onlarda merak uyandıran nitelemelerle ortama konulmuş ve öğrencilerin olumlu bir yaklaşımla sürece başlamaları amaçlanmıştır. Çevrim içi ortamda bulunan ders adları şöyledir: Sözcüklerin Sakladıkları, T11sımlı Sayılar, Doğanın Sırları, İnsan Neler Yaptı?, Sanatın Gücü, Bedenimizin Gücü.

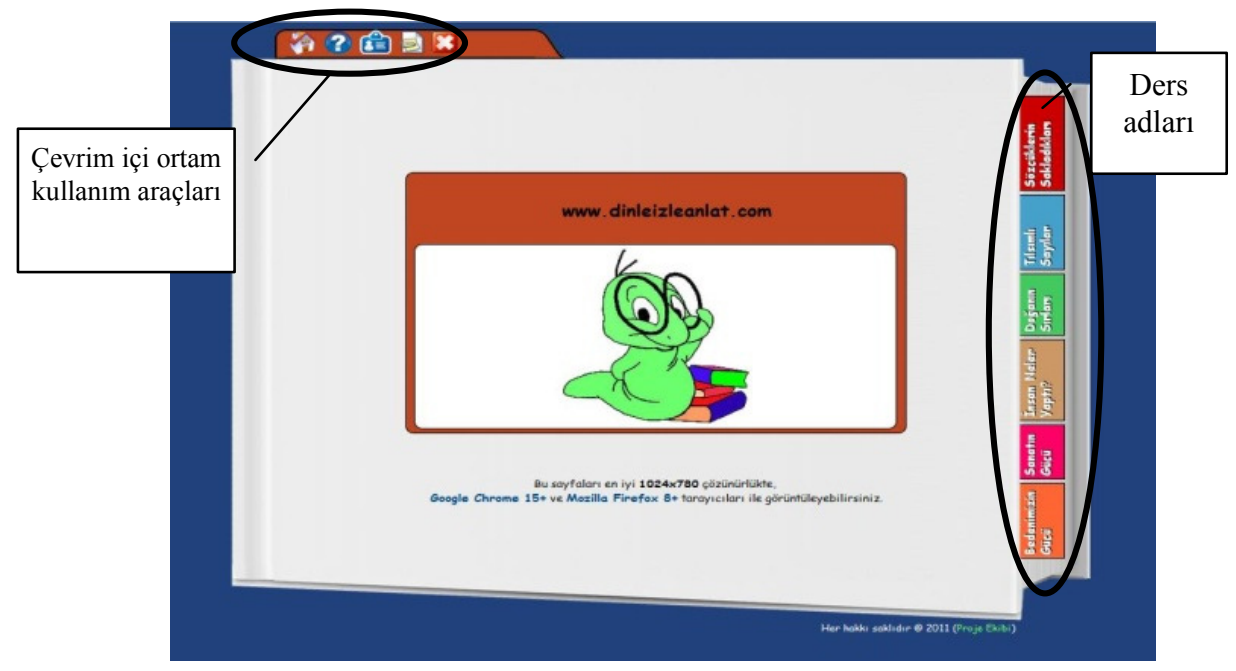

Şekil 2. Çevrim içi öğrenme ortamında kullanıcı ana sayfa görünümü

Çevrim içi ortamın farklı dersleri kapsayan bir yapıda tasarlanmasıyla bir yandan disiplinlerarası bir yaklaşım geliştirilmeye, bir yandan da dilin tüm yaşam alanlarını kapsayan bir beceriler bütünü olduğu mesajı verilmeye çalışılmıştır. Böylece bağlam oluşturulmaya, motivasyon artırılmaya ve ögrenilenlerin kullanım alanına, dolayısıyla önemine ilişkin bir anlayış geliştirilmeye çalışılmıştır. 
Ana sayfanın sol üst bölümünde çevrim içi ortam kullanım araçları bulunmaktadır (Şekil 2). Ortam kullanım araçları, öğrencilerin kolay anlamasını ve olabildiğince az yazıyla karşılaşmalarını sağlamak amacıyla sembollerle gösterilmiştir. Bu araçlardan; ev sembolü ana sayfayı, soru işareti sembolü yardımı, kimlik kartı sembolü kişisel bilgileri, ataçlı kart sembolü e-posta ve adres defterini, çarpı işareti sembolü ise siteden çıkışı ifade etmektedir

Çevrim içi ortamdaki her derse ait sayfanın sol üst bölümünde "Dinle, İzle, Anlat" başlıkları görülmektedir (Şekil 3). Çevrim içi öğrenme ortamının adıyla örtüşmesi, bütün derslerde birlik sağlanması ve etkinlik türlerinin takibinde kolaylık sağlanması için her derste "Dinle, İzle, Anlat” temaları kullanılmıştır. Bir derse tıklandığında o derse ait bütün bilgiler de seçilen dersin rengi ile aynı renkte görülmektedir. Derse ait "Dinle, İzle, Anlat" temalarından birine tıklandığında sayfanın üst orta bölümünde seçilen tema ve o temadaki paylaşımlar görülmektedir. $\mathrm{Bu}$ bölümdeki paylaşımlar ses kaydı ya da video biçimindedir. Böylece hem öğrencilerin aktif manipülatif olmalarının önü açılmış hem de yapılandırmacı doğalarının gereği farklı biçimlerde sunulan etkinliklerle karşılaşması sağlanmıştır.

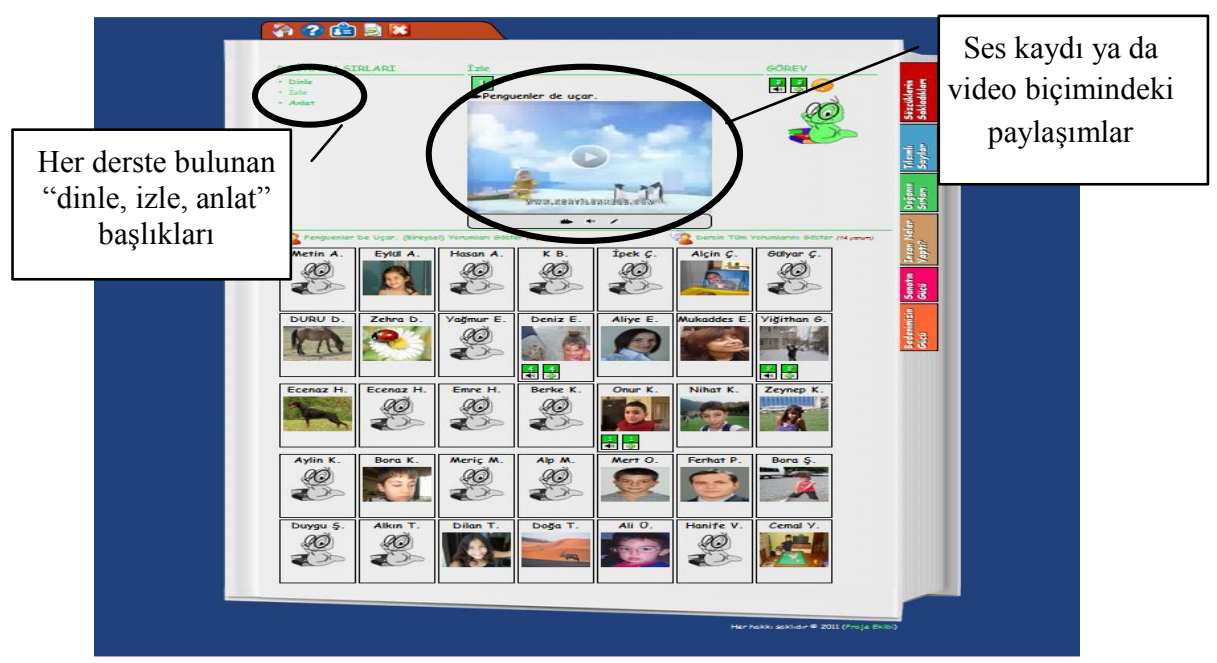

Şekil 3. Doğanın Sırları dersindeki “İzle” temasına ait ekran görüntüsü

Sayfanın üst orta bölümünde, seçilen derse ait tema adının altında rakamlar görülmektedir (Şekil 4). Bu bölümde görülen rakamlar etkinlik ve kaynak sira numarasını ifade etmektedir. Her rakama tıklandığında farklı materyaller görülmektedir. 


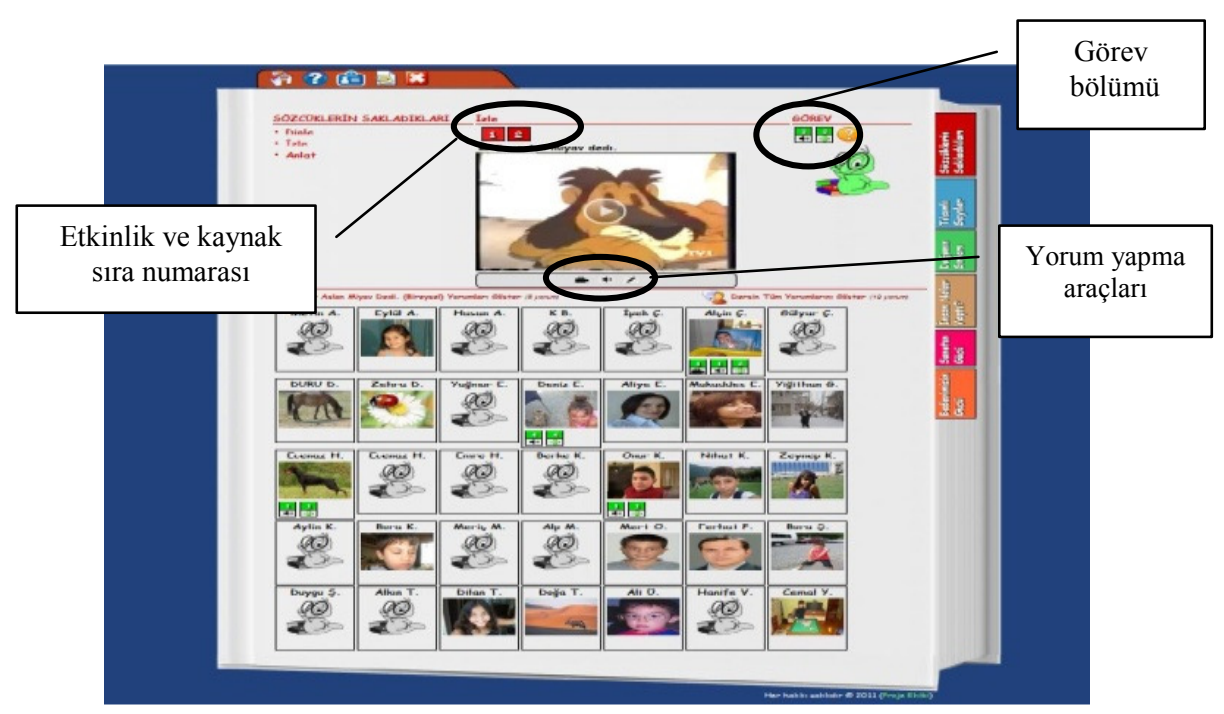

Şekil 4. Sözcüklerin Sakladlkları dersindeki “İzle” temasina ait ekran görüntüsü

Ses kaydı ya da video olarak görülen materyallerin altında üç sembol bulunmaktadır (Şekil 4). Yorum yapma araçları olarak işlev gören bu sembollerden kamera sembolü videoları, hoparlör sembolü ses kayıtlarını, kalem sembolü ise yazılı kayıtları ifade etmektedir. Bu çalışma kapsamında, araştırmada yalnızca dinleme ve konuşma becerileri üzerinde durulduğundan ögrencilerin yalnızca video ya da ses kaydı biçiminde paylaşımlar yapmaları sağlanmış; yazılı olarak paylaşım yapmalarına izin verilmemiştir.

Her derse ait sayfanın sağ üst tarafında "görev" bölümü bulunmaktadır (Şekil 4). Görev bölümünde her etkinliğe ait yönergeler ve öz değerlendirme soruları bulunmaktadır. Görev bölümünde de semboller aynı biçimde kullanılmıştır. Artı işareti sembolü toplam yönerge sayısını; soru işareti sembolü öz değerlendirme sorularını ifade etmektedir. Hoparlör ve artı sembolünün üstündeki rakamlar ise o türde yapılan paylaşım sayısını göstermektedir.

Görev bölümündeki artı sembolüne tıklandığında ses kaydı olarak paylaşılan yönerge ve sorular görülmektedir (Şekil 5). Yönerge ve sorulara ait hoparlör sembolü ya da başlığa tıklandığında ses kaydı görülmekte, yine aynı yere tıklandığında ise kapatılmaktadır. Bu bölümdeki ses kaydının altında bulunan yorum yapma araçları kullanılarak yönergede belirtilenler yerine getirilmekte ve sorular yanitlanmaktadır. 


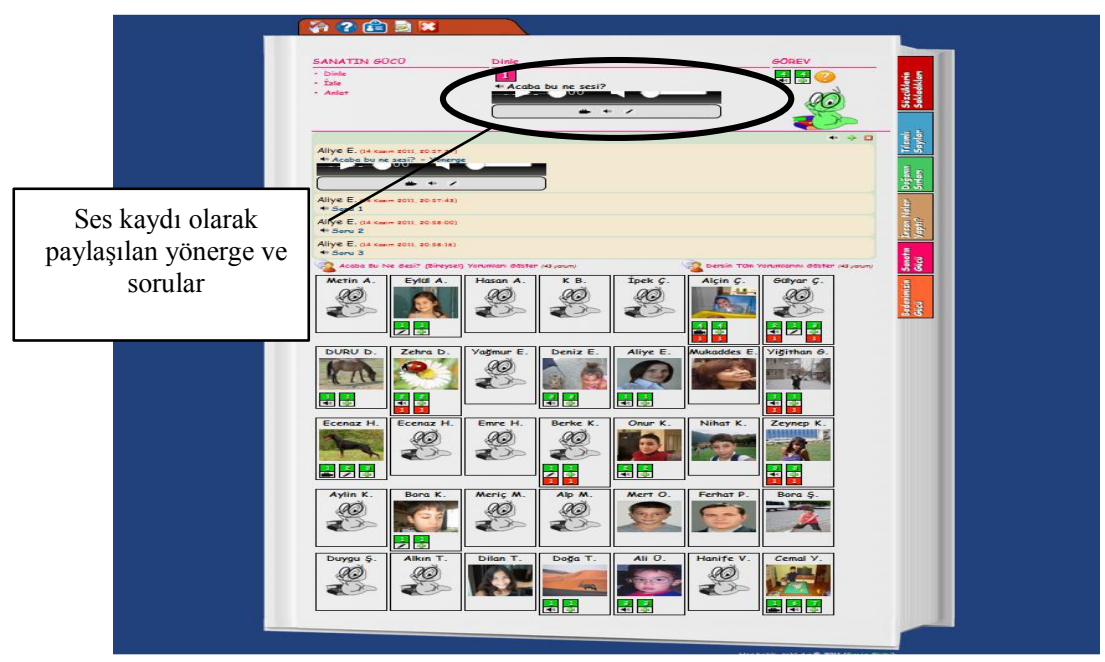

Şekil 5. Görev bölümündeki yönergeler ve sorular

Çevrim içi öğrenme ortamı, öğrencilerin bireysel çalışmaları yanında grup çalışması yapmalarını da sağlayacak biçimde düzenlenmiştir. Rastgele ya da belirlenen kişilerle, istenilen sayıda grubun oluşturulmasına uygun olması düşünülmüştür. Böylece çevrim içi öğrenme ortamının, öğrencilerin işbirlikli çalışmalar yapabilecekleri, sosyal etkileşim kurarak bilgilerini yapılandırabilecekleri bir nitelikte olması amaçlanmıştır.

Görev bölümündeki soru işareti sembolüne tıklandığında her etkinlik için belirlenen $\ddot{\boldsymbol{o} z}$ de ğerlendirme soruları görülmektedir (Şekil 6). Öz değerlendirme sorusuna tıklandığında ses kaydı ve ses kaydının altında 1-5 düzeyinde değerlendirmenin yapılabileceği rakamlar görülmektedir. 1-5 düzeyinde yapılan değerlendirmenin sonunda bu bölümün sağ alt tarafinda her etkinlik için elde edilen not ortalaması görülmektedir. 


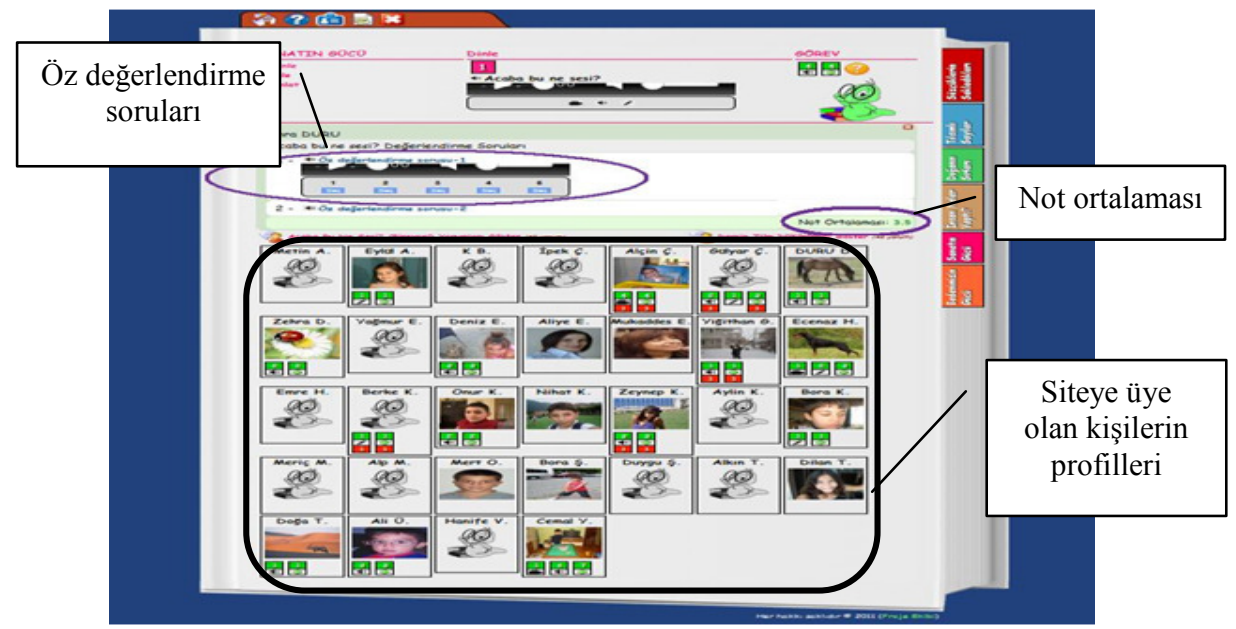

Şekil 6. Görev bölümündeki öz değerlendirme soruları ve not ortalaması

Çevrim içi öğrenme ortamında derse ait bilgilerin altındaki bölümde siteye üye olan kişilerin profilleri görülmektedir (Şekil 6). Profilde avatar olarak fotoğraf ya da resim paylaşlabilmektedir. Böylece öğrencilere seçme şansı sunularak kendi kişisel özellikleri ve tercihlerine uygun olarak profillerini kişiselleştirebilme olanağı verilmiştir.

Profildeki avatarın altında hoparlör, kamera ve artı işareti sembolleri ile yeşil ve kırmızı renklerle gösterilen rakamlar görülmektedir (Şekil 7). Yeşil kutudaki rakamlar, ait olduğu sembolde yapılan kişisel paylaşım sayısını; kırmızı kutudaki rakamlar ise başkalarının yaptığı paylaşım sayısını göstermektedir
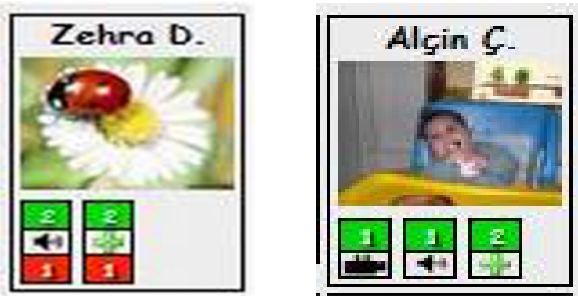

Şekil 7. Profildeki semboller ve rakamlar

Çevrim içi öğrenme ortamındaki etkinliklerde öğrenciler, kendi tercihleri doğrultusunda ses kaydı ya da video olarak paylaşım yapabilmektedir. Böylelikle öğrenciler düşünceleri, yorumları ya da çıkardıkları anlamları akıcı biçimde, sesli ya da görüntülü olarak paylaşabilmektedir. Böyle bir paylaşım, öğrencilerin kendi sesli ya da görüntülü paylaşımını tekrar dinleme/izleme olanağını sağlamasıyla kendi 
gelişim süreçlerini takip etme fursatını da vermektedir. Öğrenciler kendi paylaşımlarını eklemenin yanı sıra arkadaşlarının paylaşımlarını dinleme/izleme ve onlara yorum yapma olanağına da sahiptir. Öğrenciler ses kaydı/video gibi farklı yolları kullanarak arkadaşlarıyla iletişim kurarken bir konudaki farklı bakış açılarını da görerek eleştirel bir anlayışla onlara yönelik düşüncelerini bildirebilmektedir. Böylece etkileşim kurmaya açık bir ortamda öğrencilere, arkadaşlarının paylaşımlarını görerek ve onlara yorum yaparak kendi bilgilerini yapılandırma olanağı sunulmuştur.

\section{b) Çevrim içi ortam içerik tasarımı}

Çevrim içi öğrenme ortamında her ders, gerçekleştirilecek becerilerle ilgili temalar çerçevesinde düzenlenmiş; her tema ilgili materyaller ve görevlerle iliş̧kilendirilmiştir. Böylece bağlam tabanlı problemlere dair görevler, görevlere dayalı işbirliği ve öz değerlendirme boyutlarıyla ortam, yapılandırmacı öğrenmeyi sağlayacak niteliğe eriştirilmeye çalışılmıştır.

Çevrim içi öğrenme ortamındaki etkinliklerde animasyon, öykü, şiir, tekerleme, çizgi film, müzik gibi farklı türler kullanılarak ortamın zengin bir içeriğe sahip olması benimsenmiştir. Böylece öğrencilerin bireysel ilgi alanlarına yönelik farklı türlerdeki etkinliklerle karşılaşmaları sağlanmıştır. Etkinliklerdeki başlıkların, öğrencilerin ilgilerini çekecek ve onlarda merak uyandıracak nitelikte olmasına dikkat edilmiştir. Örneğin; "Acaba bu ne sesi?", "Penguenler de uçar." gibi.

Çevrim içi öğrenme ortamındaki derslerde, çalışma grubundaki öğrencilerin seviyesi ve yaşantılarına uygun olarak hazırlanan etkinliklerin amaçlı, anlamlı ve onları düşündürecek nitelikte olmasına dikkat edilmiştir. Etkinliklerde verilen yönergelerde öğrencilerin problem çözme, eleştirel düşünme, yorum yapma, ilişki kurma, sonuç çıkarma gibi üst düzey düşünme becerilerini geliştirmeye yönelik sorular verilmiştir. Örneğin;

- Dinlediğin ses sence ne sesidir? Bu ses nasıl ortaya çıkmış olabilir? Böyle düşünmeni sağlayan ipuçları nelerdir?

- Dinlediğin ses sana neleri anımsatıyor? Dinlediğin ile anımsadığın konu arasında nasıl bir bağlantı kurdun?

Çevrim içi öğrenme ortamındaki bütün etkinlikler, öğrencilerin etkin olması, bilgilerini kendisinin yapılandırması esasına göre hazırlanmışır. Öğrenciler bir yandan gerçek yaşamla ilgili paylaşımlar aracılığıyla sorgulamaya yönlendirilirken diğer yandan da yansıtmaya, kendi süreçleri üzerinde düşünmeye ve bunları ifade etmeye teşvik edilmiştir. Etkinliklerdeki yönergelerin video ya da ses kaydı olarak farklı türlerde 
yanıtlama olanağının sunulmasıyla öğrencilere kendilerini farklı yollarla ifade etme firsatı verilmiştir.

Değerlendirmenin öğretim sürecinden ayrı olmadan, öğretim ile birlikte yapılması düşünü̈ldüğ̈̈̈nden, çevrim içi öğrenme ortamındaki bütün etkinliklerde öz değerlendirme soruları eklenmiştir. Etkinliklerde, yapılandırmacı değerlendirme anlayışına uygun olarak, yalnızca sonucun değil, öğretim sürecindeki gelişimin/ilerlemenin de değerlendirilmesi amaçlanmıştır. Diğer yandan öğretim sürecinde olduğu gibi değerlendirmenin de yansıtıcı nitelikte olmasına özen gösterilmiş, öğrencilerin kendi dinleme ve konuşma süreçlerini fark etmeleri, gözlemlemeleri ve bu süreçlerdeki gelişimlerini değerlendirmeleri sağlanmıştır.

\section{c) Yüz yüze öğrenme ortamının oluşturulması}

Araştırmanın yüz yüze boyutunda uygulanan etkinlikler, araştırma kapsamında belirlenen dinleme ve konuşma becerisi yeterliklerinin yanı sıra MEB ilköğretim 4. sınıf Türkçe dersi dinleme ve konuşma öğrenme alanlarındaki kazanımlar da dikkate alınarak düzenlenmiş; böylelikle araştırmanın, sınıftaki doğal süreci kesintiye uğratmasının önüne geçilmeye çalışılmıştır.

Yüz yüze öğrenme ortamında uygulanacak etkinlikler için gerekli olan araç gereçler sağlanmış ve sınıf ortamına getirilmiştir. Bu araç gereçlerden bazıları ses çıkarmada kullanılan bardak, kaşık, cam şişe, oyuncak; dinleme nesnesi olarak ses kaydı, video, çizgi film, şiir ve görsellerdir. Yüz yüze öğrenme ortamında kullanılan materyallerde gerçek ses çıkaran nesneler kullanılmıştır. Böylece öğrencilerin ses kaynaklarına dikkatlerini çekerek onları dinlemeye odaklamak amaçlanmıştır.

Sınıfta gerçekleştirilecek etkinliklere göre öğrencilerin oturma düzenlerinde değişiklikler yapılmış; sıralar bazen küçük gruplarla çalışılabilecek şekilde düzenlenirken bazen daire biçiminde düzenlenmiştir. Öğrenciler bireysel olarak çalışma yanında, ikili çalışmalar, tartışma ya da grup çalışmaları yapmıştır.

Yüz yüze öğrenme ortamında öğrencilere, çevrim içi öğrenme ortamında paylaşılmış ya da paylaşılacak olan etkinlikler hakkında bilgi verilmiştir. Çevrim içi öğrenme ortamındaki yönergelere verilen yanıtlar, öğrencilerin yorumları gibi paylaşımlar hakkında tartışılmıştır. Ayrıca her hafta en fazla paylaşımda bulunan üç öğrenci ödüllendirilmiştir. Böylece öğrenciler çevrim içi öğrenme ortamını kullanmak için yönlendirmeye ve özendirilmeye çalışılmıştır. 
Yüz yüze öğrenme ortamında her öğrencinin, kendisinin belirleyeceği bir konuda hazırlık yaparak beșer dakikalık bir sözlü anlatım yapması sağlanmıştır. Öğrenciler hazırladıkları konuda, sınıf içinde arkadaşlarının önünde anlatımını gerçekleștirmiștir. Böyle bir etkinlik ile öğrencilerin konuyu belirleme aşamasından sunma aşamasına kadar sözlü anlatım sürecinin her boyutunu deneyimlemesi firsatı verilmiştir. Diğer yandan sınıftaki diğer öğrencilerin de konuşmacıyı dinlerken dinleme sürecinin özelliklerini yansıtmaları amaçlanmıştır. Öğrenciler kendi sunumlarını yaparken kendilerinin getirdikleri materyalleri de kullanmışlardır. Her öğrencinin sözlü anlatımının ardından hem her öğrenci kendisini değerlendirmiş hem de arkadaşları sunan kişiyi değerlendirmiştir. Böylece değerlendirme, uygulama sürecinin bir parçası olarak gerçekleştirilmiştir. Farklı zamanlarda yapılan dinleme ve konuşmaya dayalı etkinliklerde ise öğrencilerin bu alanlarda kendilerindeki gelişimi değerlendirmeleri de sağlanmıştır.

Yüz yüze öğrenme ortamında öğrencilerin, bir metnin kurallı ve kuralsı biçimde okunuşunu ses kaydından dinlemeleri sağlanmış ve her iki okuma arasındaki farklılıkları belirlemeleri sağlanmıştır. Aynı metin ile ilgili iki farklı ses kaydı dinlenerek konuşmanın etkili olabilmesi için hangi niteliklere sahip olması gerektiği konusunda tartışılmıştır. Böylece öğrencilerin etkili bir konuşmanın özelliklerini kendilerinin bulması sağlanmıştır. Daha sonraki etkinliklerde ise anlatımlar belirlenen bu özelliklere göre değerlendirilmiştir.

\section{Uygulama Çalışmaları}

Karma öğrenme ortamının çevrim içi ve yüz yüze boyutlarında gerçekleştirilen uygulamalarda dikkat edilen ilkeler açıklanmıştır.

\section{Çevrim içi öğrenme ortamının uygulanmast}

Karma öğrenme ortamındaki etkinlikler, sınıf öğretmeninin ders planları dikkate alınarak geliştirilmiştir. Uygulama, yüz yüze ve çevrim içi etkinlikler birbirini tamamlayacak biçimde düzenlenmiş ve araştırmacı tarafindan gerçekleştirilmiştir. Uygulama süreci, okulun Türkçe dersi kapsamındaki etkinliklerini ve sınıfın diğer derslerdeki çalışmalarını aksatmayacak biçimde ders programını değiştirmeden yürütülmüştür. Araştırmacı hazırladığı etkinlikleri sınıfa götürmüş, öğrencilerle çalışmış; çevrim içi ortamı açıklamış ve katılım konusunda öğrencileri motive edecek ödüllendirici uygulamalar gerçekleştirmiştir. Öğrencilerin çevrim içi ortam ile ilgili her türlü soruları anında yanıtlanmış ve çevrim içi ortamın kullanımıyla ilgili yaşadıkları sorunlar hemen çözülmüştür. 
İlköğretim dördüncü sınıf düzeyinde haftada 6 saat Türkçe dersi bulunmaktadır. $\mathrm{Bu}$ sürenin her hafta için 3-4 saatlik dilimi bu araştırma için kullanılmıştır. Uygulama, 14 Kasım 2011 - 13 Ocak 2012 tarihleri arasında gerçekleştirilmiş ve toplam 8 hafta (30 saat) sürmüştür. Bu süre içinde dinleme ve konuşma becerileri kapsamında geliştirilmesi düşünülen tüm beceriler için gerekli çalışmalar gerçekleştirilebilmiştir.

Çevrim içi ortamda paylaşılan etkinliklerle yüz yüze ortamda gerçekleştirilen etkinlikler paralel düzenlenmiştir. Çevrim içi öğrenme ortamında öğrencilerden, paylaşılan ses kaydını dinledikten ya da videoyu izledikten sonra, dinleme ve konuşma becerilerine yönelik verilen görevleri yerine getirmeleri ve belirlenen yeterlikler bakımından kendilerini değerlendirmeleri istenmiştir. Ayrıca öğrencilere, diğer arkadaşlarının paylaşımlarını dinleyerek/izleyerek, onların paylaşımlarına yönelik görüş bildirme ve grup çalışmaları yapma olanakları da sunulmuştur.

\section{Yüz yüze öğrenme ortamının uygulanması}

Karma öğrenme ortamının yüz yüze boyutunda da yapılandırmacı ilkeler uygulanmaya çalışılmıştır. Yüz yüze öğrenme ortamında uygulanan etkinlikler, sınıf içinde gerçekleştirmeye uygun olarak belirlenen dinleme ve konuşma becerilerinin geliştirilmesi esasına dayalı olarak hazırlanmıştır. Dinleme ve konuşma becerilerini geliştirmeye yönelik hazırlanan etkinlikler öğretmenin ders planlartyla bütü̈nleștirilmiş; dinleme ve konuşma becerileri, öğrenme stratejileriyle birlikte düşünülmüştür. Örneğin; yerleşim yöntemi, baş harflerle düzenleme, kavram haritası gibi. Böylece öğrencilerin bütün derslerde ve hayat boyu kullanacakları temel dil becerilerinden dinleme ve konuşma becerileri ile öğrenme stratejileri bütünleştirilerek hem bağlam oluşturulmuş hem de öğrencilere kendi bireysel özellikleri ve tercihlerine uygun öğrenme yollarını seçme olană̆ sunulmuştur.

Dinleme ve konuşma becerilerini geliştirmeye yönelik hazırlanan etkinlikler, öğrencilerin hem bireysel olarak etkin olmalarını hem de grupla etkileşim kurmalarını olanaklı kılacak biçimde düzenlenmiştir. Örneğin; hazırlık yaparak sınıfta bireysel olarak sunulan konuşma, grup çalışması yaparak hikâyenin sonunu tamamlama etkinlikleri gibi. Bireysel ya da grup çalışmasıyla gerçekleştirilen etkinliklerin ardından öğrencilerin kendi dinleme ve konuşma süreçleri hakkında düşünmeleri ve değerlendirmelerini paylaşmaları sağlanmıştır. Böylelikle gerçekleştirilen bireysel ve grup çalışmalarıyla, öğrencilerin yapılandırmacı doğalarına uygun olarak ögrenme-öğretme sürecinde hem etkin olmaları sağlanmış hem de işbirlikli çalışmalar ile ögrenenler arasında sözel paylaşımlar kurmaları 
desteklenmiştir. Ayrıca gerçekleştirilen bireysel ve grup çalışmaları sonunda, yapılandırmacı anlayışın bir gereği olarak, öğrenciler kendi süreçleri üzerinde düşünmeye ve bunları ifade etmeye teşvik edilmiştir.

Yüz yüze öğrenme ortamında gerçekleştirilen etkinlikler bazen sadece dinlemeye, bazen de izlemeye yönelik olarak hazırlanmuştır. Örneğin; ses kaydından hikaye, şiir, tekerleme dinleme, araştırmacı tarafından anlatılan örnek olayı dinleme; projeksiyon ile sınıfa yansıtılan çizgi film, animasyon ya da kısa filmi izleme gibi. Böylece öğrencilerin farklı biçimlerde sunulan dinlemeye ve izlemeye dayalı etkinliklerle buluşması sağlanırken, ilgi ve merak duyguları da sürekli yüksek tutulmaya çalışılmıştır. Ayrıca dil becerilerinin, farklı türlerde kullanılan materyallerle geliştirilebileceği mesajı verilmeye çalışılmıştır.

Yüz yüze öğrenme ortamında gerçekleştirilen etkinliklerde gerçek hayattan örnek olaylar sunulmuş, öğrencilerin paylaşılan örnek olaya ilişkin çıkarımlar, yorumlar, değerlendirmeler yapması ve öneriler geliştirmesi istenmiştir. Böylece öğrenciler için ilginç ve çekici olabilecek, onların sürece katılmalarını özendirecek etkinliklerin uygulanmasıyla gerçek hayatta karşılaşılabilecekleri, anlamlı bir durum ile etkileşim kurması sağlanmıştır.

Yüz yüze öğrenme ortamında gerçekleştirilen etkinliklerden biri de, öğrencilerin grup tartışması yapmalarıdır. Tartışmayı yapacak olan öğrenciler tarafından belirlenen bir konuda iki farklı görüşü savunan iki ayrı grup, grup görüşlerine uygun olacak biçimde tartışmıştır. Örneğin; teknolojinin hayatımıza kattığ 1 olumlu özellikler ile teknolojinin getirdiği olumsuz özellikler konusu gibi. Böyle bir çalışmayla öğrencilerin güdülenerek ve üyesi oldukları grup ile etkileşim kurarak etkinliğe ilgiyle katılması sağlanmıştır. Dinleme ve konuşma becerilerinin birlikte kullanılmasını gerektiren böyle bir etkinlik aracılığıyla öğrencilerin bu becerilerin kullanım alanlarını da fark etmeleri sağlanmaya çalışılmıştır. Ayrıca grup tartışması etkinliğine ait video kayıtlarının çevrim içi ortamda paylaşılmasıyla öğrencilere, hem kendi, hem de diğer arkadaşlarının dinleme ve konuşma süreçlerini izleme ve değerlendirme olanağı sunulmuştur.

Çevrim içi ortamda olduğu gibi, yüz yüze öğrenme ortamında gerçekleştirilen etkinliklerde de ilkokul dördüncü sınıf öğrencisinin gelişim özellikleri, ilgi alanları, ön bilgileri ve kavrama düzeyi dikkate alınmış; yazınsal nitelikli eserlerden bölümler seçmeye, görsellerin ise öğrencilerin düzeyine uygun olmasına özen gösterilmiştir. Farklı türlerde dinleme ve izleme materyalleri kullanılarak zengin bir öğrenme ortamında öğrencilerin dinleme ve konuşma becerileri geliştirilmeye çalış1lırken aynı zamanda öğrenme sürecinde, motivasyonlarının devamlılı̆̆ını sağlamak amaciyla, 
keyifli ve eğlenceli zaman geçirmeleri önemsenmiştir. $\mathrm{Bu}$ doğrultuda gerçekleştirilen bazı etkinlikler; tekerleme söyleme, karikatür yorumlama, konuşma balonunda boş bırakılan ifadeyi tahmin etme, bilmece sorma, doğaçlama ya da canlandırma yapma, oyun oynama, sınıfça hikâye oluşturma, hikâye tamamlama gibi.

Yüz yüze öğrenme ortamında gerçekleştirilen etkinliklerde; bağlama dayalı gerçek hayat senaryolarıyla sunulan problem durumlarında aktif olma, grup çalışmalarında grup üyeleriyle işbirliği yapma ve etkileşim kurma, bireysel özelliklerine uygun öğrenme yollarını seçme ve kendi öğrenme süreçlerini değerlendirme özellikleriyle ortamın yapılandırmacı bir öğrenme ortamı niteliklerini taşımasına çalışılmıştır. Geliştirilen ortamın değerlendirilmesi ile ilgili bilgiler değerlendirme sürecinde verilmiştir.

\section{Değerlendirme Süreci (Öğrencilerin geribildirimlerine ilişkin bulgular ve yorumlar)}

Karma öğrenme ortamının değerlendirilmesi, uygulamalar sırasında öğrencilerin tasarıma ve uygulamalara verdikleri geri bildirim ile çevrim içi öğrenme ortamına katılım oranına dayalı olarak gerçekleştirilmiştir. Değerlendirmede öğrencilerin çevrim içi öğrenme ortamına katılım oranlarını ve etkileşimlerini belirlemek amacıyla çevrim içi öğrenme ortamı kayıtları incelenmiş; çevrim içi öğrenme ortamındaki etkinliklere ait görevler kapsamında gerçekleştirdikleri video ya da ses kayıtlarının, arkadaşlarının paylaşımlarına yönelik ses kaydı ya da video biçiminde yaptıkları yorumların ve öz değerlendirme sorularına verdikleri yanıtların sayısı belirlenmiştir. Sonuçlar Tablo 2'de sunulmuştur.

Tablo 2. Çevrim içi öğrenme ortamındaki etkinlikler ile öğrenci paylaşımlarının derslere ve temalara göre dă̆ılımı

\begin{tabular}{|c|c|c|c|c|c|c|c|c|c|c|c|c|c|c|}
\hline \multirow{2}{*}{ Tersler } & \multicolumn{2}{|c|}{$\begin{array}{l}\text { Sözcüklerin } \\
\text { Sakladıklar1 }\end{array}$} & \multicolumn{2}{|c|}{$\begin{array}{l}\text { T1lsiml } \\
\text { Sayilar } \\
\end{array}$} & \multicolumn{2}{|c|}{$\begin{array}{c}\text { Doğanın } \\
\text { Sirları } \\
\end{array}$} & \multicolumn{2}{|c|}{$\begin{array}{c}\text { İnsan Neler } \\
\text { Yaptı? }\end{array}$} & \multicolumn{2}{|c|}{$\begin{array}{l}\text { Sanatın } \\
\text { Gücü }\end{array}$} & \multicolumn{2}{|c|}{$\begin{array}{l}\text { Bedenimizin } \\
\text { Gücü }\end{array}$} & \multicolumn{2}{|c|}{ Toplam } \\
\hline & 晜焉 & 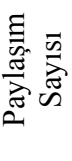 & $\frac{1}{\partial}$ & 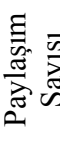 & & 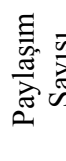 & 羕 & 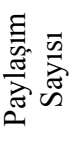 & 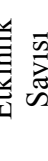 & 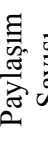 & 禀 & 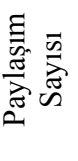 & 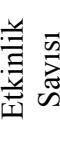 & 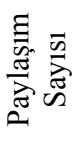 \\
\hline Dinle & 3 & 13 & - & - & 2 & 16 & 2 & 5 & 1 & 60 & 1 & 5 & 9 & 99 \\
\hline İzle & 3 & 30 & 1 & 7 & 1 & 11 & 2 & 13 & 1 & 5 & 1 & 4 & 9 & 70 \\
\hline Anlat & 4 & 20 & 1 & 6 & - & - & 3 & 4 & 1 & 5 & - & - & 9 & 35 \\
\hline Toplam & 10 & 63 & 2 & 13 & 3 & 27 & 7 & 22 & 3 & 70 & 2 & 9 & 27 & 204 \\
\hline
\end{tabular}


Tablo 2'de görüldüğü gibi, çevrim içi ortamda "dinle", "izle" ve "anlat" temalarının her birinde 9 etkinlik olmak üzere toplam 27 etkinlik paylaşılmıştır. Öğrenciler; "dinle" temasında 99 (91 ses kaydı, 8 video), "izle" temasinda 70 (63 ses kaydı, 7 video) ve "anlat" temasinda 35 (30 ses kaydı, 5 video) olmak üzere toplam 204 (184 ses kayd1, 20 video) paylaşımda bulunmuştur. Çevrim içi öğrenme ortamına eklenen ilk üç etkinlik sırayla; Sanatın Gücü dersi "dinle" teması, Doğanın Sırları dersi "izle" teması ve Sözcüklerin Sakladıkları dersi "dinle" temasında olmuştur. Çevrim içi ortama en son Bedenimizin Gücü dersi "izle" temasında etkinlik eklenmiştir.

Öğrencilerin çevrim içi öğrenme ortamındaki etkinliklere katılım durumu incelendiğinde ortama ilk eklenen etkinliklerde daha fazla paylaşım yaptıkları, çalışmanın ilerleyen zamanlarında ise katılım durumlarının düştüğü görülmektedir. Öğrenciler böyle bir ortamla ilk kez karşılaştıkları için ilk etkinliklere daha fazla ilgi gösterdikleri söylenebilir. Diğer yandan öğrencilerin etkinliklerdeki yönergelere verdikleri yanıtların türü incelendiğinde öğrencilerin video yerine daha çok ses kaydı kullanarak yanıtlamayı / yorum yapmayı tercih ettikleri görülmektedir.

Dinle, izle ve anlat temalarında eşit sayıda etkinlik paylaşılmış olmasına karşın ögrenciler en fazla "dinle" temasında, en az ise "anlat" temasında paylaşım yapmıştır. Bu bulgu, öğrencilerin daha önce yalnızca dinleme becerisine yoğunlaşan etkinliklerle karşılaşmadıkları ve çevrim içi ortamda dinleme becerisi ile ilgili paylaşılan etkinliklerin diğerlerine göre öğrencilerin ilgisini daha fazla çektiği düşünülerek bu türde daha fazla paylaşım yaptıkları şeklinde yorumlanabilir. Diğer yandan öğrencilerin "anlat" temasındaki paylaşım sayısının, diğer iki temanın yaklaşık yarısı kadar olması ise dikkat çekicidir. Bu durum, öğrencilerin çevrim içi ortamda konuşma yerine dinleme ve izlemeyi daha çok tercih ettiği biçiminde yorumlanabilir.

Karma öğrenme ortamının çevrim içi boyutunun kullanım düzeyine bakıldığında, çevrim içi ortamın öğrenciler tarafından beklenilen düzeyde kullanılmadığ1 görülmektedir. Öğrenciler çevrim içi öğrenme ortamına eklenen ilk etkinliklere daha fazla ilgi gösterirken ilerleyen zamanda katılım düzeylerinin düştügü görülmüştür. Öğrenciler okul dış1 zamanlarında katıldıkları sportif ya da sanatsal etkinliklerin çok zaman alması ya da dersleri kapsamında yapılan çalışmalar nedeniyle çevrim içi ortama daha az zaman ayırmak durumunda kaldıklarını ifade etmişlerdir. Çevrim içi ortam ile ilgili çalışmaların araştırmacı tarafından yürütülmesi, süreç içinde sınıf öğretmeninin ortamı kullanmaması ve kullanılmasına yönelik yönlendirmeler yapmamasının bu sonucun ortaya çıkmasında etkisinin olduğu düşünülmektedir. Diğer yandan geliştirilen böyle bir ortamın ilk kez 
uygulanmasıyla bazı teknik sorunlarla da karşılaşılmıştır. Her ne kadar teknik sorunlar en kısa sürede çözülmeye çalışılmışsa da sürecin planlandığ 1 biçimde yürütülmesinde aksamalara neden olmuştur.

Arkün ve Aşkar'a (2010) göre video, bilgisayar, fotoğraf ve ses gibi diğer iletişim yollarıyla oluşturulan ortamlar öğrenciyi kendini farklı yollarla ifade etme konusunda da cesaretlendirir. Çevrim içi öğrenme ortamında ögrencilerden, paylaşılan ses kaydını dinledikten ya da videoyu izledikten sonra, dinleme ve konuşma becerilerine yönelik verilen görevleri yerine getirmeleri ve belirlenen yeterlikler bakımından kendilerini değerlendirmeleri istenmiştir. Brooks ve Brooks'un (1993) belirtiği gibi, yalnız ürüne değil; performansına, gelişimine, öğrenme-öğretme surecinde yaptıklarına, çevresiyle ve arkadaşlarıyla olan ilişkilerine bakarak değerlendirme, öğrenme sürecinin içinde yapılmıştır. Ayrıca öğrencilere, diğer arkadaşlarının paylaşımlarını dinleyerek/izleyerek, onların paylaşımlarına yönelik görüş bildirme fırsatı da sunulmuştur. Çevrim içi öğrenme ortamında gerçekleştirilen etkinliklerdeki öğrenci paylaşımlarından bazıları yazılı biçime dönüştürülerek aşağıda verilmiştir:

\footnotetext{
"Yağmur sesi olduğunu düşündüm. Çünkü kışın yă̆an yă̆mur sesini çok dinlediğim için yabancı gelmedi. Bana sonbahar ve kışı hatırlatıyor. Çünkü sonbahar ve klşta çok yağmur yağar. Başında üşüdüm, aklıma düşen yapraklar geldi, ancak sonlara doğru aklıma sıcak bir çay geldi ve isındım."
}

\section{“Bu kaydı dinlerken merak ettim."}

"Ben de ... arkadaşıma katılıyorum. Benim de böyle bir şaşkınlığım oldu. Insanlar ellerini şıklatarak yani ben yapamıyorum. Yani nasıl yağmur sesi çıkardıklarını anlayamadım. Ben de ilk başta yağmur sesi çıkardıklarını sanmıştım. Ben biraz üzülddüm çünkü tahminim yanlış çıkmıştı. Baktım bir arkadaşımda da benim tahminim çıkmış. Yağmurun yere vurma sesi diye düşünmüştüm ama birçok insanın orkestra şeklinde parmak şıklatma, davul çalma gibi sesleriymiş. Onun dışında videoyu izlerken, müzik dersinde işime yarayacak bir videoydu.”

"Ben penguenlerin uçtuğunu biliyordum ama bu filme göre uçamıyorlarmış ve oradaki adamın Antarktika'ya gitmesine de inanamadım."

"Dinlemenin başında biraz güldüm, çünkü penguenler öyle uçunca biraz komiğime gitti. Adamda öyle bir yüz vardı ki, yani gülmemek mümkün değil. Çok güzel bir videoydu, çok eğlendim. Çok komik bir videoydu. Dinlemenin sonunda bile güldüm. Dinleme boyunca güldüm." 
"Ben bu ses kaydinda ördek, civciv, ayl, eşek, at, inek, tavuk ve horoz sesi duydum. Bu ses kaydı bana biraz gülünç geldi. Çünkü horozun sesi, atın, ineğin sesi yani ilk defa duydum bu sesleri. İyi ki böyle bir site açılmış. Bunlar sayesinde gelecekte daha iyi bir meslek düşünebilirim.”

“Aslında çok haklı olabilirsin, ben bunu hiç düşünmemiştim.”

"Sünger Bob filmindeki kişileri şöyle ilişkilendirerek yorumluyorum; olaylar hep birbirine bağl, Sünger Bob ilk önce bir hayal görüyor, bu hayalin gerçekleşeceğini biliyor. Sonra arkadaşlarına gidiyor. Böyle ilişkilendiriyorum. Önceki bilgilerim arasında bir kronolojik sıra bilgisi var.."

"Dinlemeyi sadece kulaklarımızla yapabiliriz. Bu çok dikkatli bir dinleme gerçekleş̧tirmez. Ama beynimizle dinlersek konuşmacının bize ne demek istediğini daha iyi anlarız. Ellerimizle dinlemek istersek elimizde bir şey olmamal ve parmaklarımızla oynamamaltyı. Ayaklarımızla da dinleyebiliriz. Bunun sebebi ayaklarımız yere vurmazsak daha iyi konsantre olabileceğimizdendir. Bunun dışında gözlerimizle de dinleriz, dinleyicinin gözlerine bakarı. Böylece tüm vücudumuzla dinlemek mümkündür. Strtımızı geriye yaslayı dik oturursak, bu hem bizim dikkatimizi uyandırtr hem de konuşmactya saygımızı gösterir.”

Çevrim içi öğrenme ortamındaki öğrenci paylaşımları incelendiğinde, öğrencilerin çevrim içi öğrenme ortamına yönelik belirttikleri görüşler, $\mathrm{Wu}$, Tennyson ve Hsia'nın (2010) araştırma sonucuyla örtüşmekte; öğrenciler çevrim içi öğrenme ortamını çok yoğun kullanmamış olmalarına karşın, ortamdaki etkinliklerin onların ilgisini çektiği, onlarda merak uyandırdığı ve ortamdaki etkinliklere keyifle katılmalarını sağladığı görülmektedir. Ayrıca paylaşımlar yoluyla öğrencilerin kaygıları, ön yaşantıları, merakları, kendilerini ifade etme güçleri, yaratıcılıkları gibi birçok özelliklerini görme firsatı bulunmuştur. Bunlar düzenlenecek öğrenme öğretme etkinlikleri için önemli ipuçları olabilir.

Çevrim içi öğrenme ortamında paylaşılan etkinliklerle yüz yüze öğrenme ortamında gerçekleştirilen etkinlikler paralel biçimde düzenlenmiştir. Osguthorpe ve Graham'ın (2003) belirttiği gibi çevrim içi erişim ile yüz yüze etkileşim arasında uyumlu bir dengeyi kurulmuştur. Karma öğrenme ortamının yüz yüze boyutunda öğrencilerin gerek bireysel gerekse de grupla gerçekleştirilen etkinliklere katılımının oldukça iyi olduğu söylenebilir. Öğrenciler yüz yüze ortamda yüksek bir motivasyon ile gereken hazırlıkları yapmış, tartışmalara katılmış, soruları yanıtlamış ve gerçekleştirilen etkinliklere katılmıştır. 


\section{SONUÇ VE ÖNERILER}

Dinleme ve konuşma iki temel dil becerisidir ve bu becerilerin geliştirilmesi okul öğrenmelerinin temel hedefleri arasında yer alır. $\mathrm{Bu}$ becerilerin birbirinden ve diğer dil becerilerinden bağımsız olarak kazandırılmaları ve ölçülmeleri konusunda önemli güçlükler bulunmaktadır. Buradan hareketle bu araştırmada, karma öğrenme ortamlarının söz konusu güçlüğü aşmada işlevsel olabileceği düşünülmüş ve paylaşımların büyük ölçüde dinleme ve konuşma yoluyla gerçekleştirildiği bir karma öğrenme ortamı modeli geliştirilmiştir. Karma öğrenme ortamının bir yönünü yüz yüze uygulamalar oluştururken diğer yönünü çevrim içi etkinlikler oluşturmaktadır. Çevrim içi etkinlikler "www.dinleizleanlat.com" adlı çevrim içi ortam üzerinden gerçekleştirilmiştir.

Çevrim içi ortamda "dinle", "izle" ve "anlat" temalarının her birinde 9 etkinlik olmak üzere toplam 27 etkinlik sunulmuştur. Video ya da ses kaydı yaparak yorumlarını iletmeleri istenen öğrenciler; "dinle" temasında 99 (91 ses kayd1, 8 video), "izle" temasinda 70 (63 ses kaydı, 7 video) ve "anlat" temasında 35 (30 ses kaydı, 5 video) olmak üzere toplam 204 (184 ses kaydı, 20 video) paylaşımda bulunmuştur.

Öğrenciler video yerine daha çok ses kaydı kullanarak yorum yapmayı tercih etmişlerdir. Bu durum çevrim içi ortama ses kaydının ortam üzerinden yapılabilmesi, video kaydının ise bir dış ortamdan yapılmak durumunda olmasıyla ilişkili olabilir. Kullanıcının güçlük yaşadığı ya da güçlük olarak algıladığı uygulamalar çevrim içi ortamların kullanım oranını düşürmektedir.

Dinle, izle ve anlat temalarında eşit sayıda etkinlik paylaşılmış olmasına karşın ögrenciler en fazla "dinle" temasında, en az ise "anlat" temasında paylaşım yapmıştır. "Anlat" temasındaki paylaşım sayısı, diğer iki temanın yaklaşık yarısı kadardır. Bu durum, öğrencilerin çevrim içi ortamda konuşma yerine dinleme ve izlemeyi daha çok tercih ettiği biçiminde yorumlanabilir.

Karma öğrenme ortamının çevrim içi boyutu beklenilen düzeyde kullanılmamıştır. Öğrenciler çevrim içi öğrenme ortamına eklenen ilk etkinliklere daha fazla ilgi gösterirken ilerleyen zamanda katılım düzeylerinin düştüğü görülmüştür. Bu durum yenilik etkisiyle açıklanabilir, öğrenciler böyle bir ortamla ilk kez karşılaştıkları için ilk etkinliklere daha fazla ilgi göstermiş olabilir. Ayrıca öğrenciler okul dışı zamanlarında katıldıkları sportif ya da sanatsal etkinliklerin çok zaman alması ya da dersleri kapsamında yapılan çalışmalar nedeniyle çevrim içi ortama daha az zaman ayırmak durumunda kaldıklarını ifade etmişlerdir. Çevrim içi ortam ile ilgili çalışmaların araştırmacı tarafından yürütülmesi, süreç içinde sınıf öğretmeninin ortamı kullanmaması ve kullanılmasına yönelik 
yönlendirmeler yapmamasının bu sonucun ortaya çıkmasında etkisinin olduğu düşünülmektedir.

Diğer yandan geliştirilen böyle bir ortamın ilk kez uygulanmasıyla bazı teknik sorunlarla da karşılaşılmıştır. Her ne kadar teknik sorunlar en kısa sürede çözülmeye çalışılmışsa da sürecin planlandığı biçimde yürütülmesinde aksamalara neden olmuştur.

Çevrim içi öğrenme ortamındaki öğrenci paylaşımları incelendiğinde, öğrencilerin çevrim içi öğrenme ortamına yönelik belirttikleri görüşler, $\mathrm{Wu}$, Tennyson ve Hsia'nın (2010) araştırma sonucuyla örtüşmekte; öğrenciler çevrim içi öğrenme ortamını çok yoğun kullanmamış olmalarına karşın, ortamdaki etkinliklerin onların ilgisini çektiği, onlarda merak uyandırdığı ve ortamdaki etkinliklere keyifle katılmalarını sağladığı görülmektedir. Ayrıca paylaşımlar yoluyla öğrencilerin kaygıları, ön yaşantıları, merakları, kendilerini ifade etme güçleri, yaratıcılıkları gibi birçok özelliklerini görme firsatı bulunmuştur. Bunlar düzenlenecek öğrenme öğretme etkinlikleri için önemli ipuçları olabilir. Birkaç örnek:

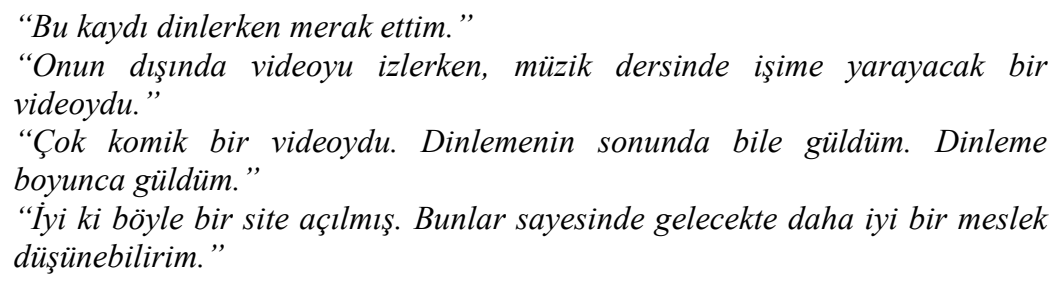

Karma öğrenme ortamının yüz yüze boyutunda öğrencilerin gerek bireysel gerekse de grupla gerçekleştirilen etkinliklere katılımının oldukça iyi olduğu söylenebilir. Öğrenciler yüz yüze ortamda yüksek bir motivasyon ile gereken hazırlıkları yapmış, tartışmalara katılmış, soruları yanıtlamış ve gerçekleştirilen etkinliklere katılmıştır.

Çalışma, dil becerilerinin geliştirilmesinde karma öğrenme ortamının işlevsel olabileceğine dair sonuçlar üretmiştir. Öte yandan özellikle çevrim içi ortamın düzenlenmesinde ve kullanılmasında bazı noktalara dikkat etmek etkililiği artırabilir.

- Ortamdaki tüm uygulamaların öğrenciler için kolay olmasına dikkat edilmelidir.

- Ortamda yaşanabilecek teknik sorunlar sürekli kontrol edilerek giderilmelidir.

- Ögretmen ortamın aktif katılımcısı olmalıdır.

- Çevrim içi ortamda yapılan etkinlikler yüz yüze etkinliklerin başlatıcısı ya da devamı olarak düzenlenmelidir.

- Sürekli uygulama ve dikkatli gözlemlerle daha etkili çevrim içi ortamlar geliştirilebilir. 


\section{KAYNAKLAR}

Abdal-Haqq, I. Constructivism in teacher education: considerations for those who would link practice to theory. http://www.ericdigests.org/1999-3/theory.htm (Erişim Tarihi: 15.09.2012)

Arkün, S. ve Aşkar, P. (2010).Yapılandırmacı öğrenme ortamlarını değerlendirme ölçeğinin geliştirilmesi. Hacettepe Üniversitesi Eğitim Fakültesi Dergisi, (39)32-43.

Arkün, S., Erdem, M. (2007) "BİT Destekli Öğretmen Eğitimi Modelleri Üzerine Bir İnceleme”, Uluslararası Ögretmen Yetiştirme Politikalart ve Sorunlart Seтровуити Bildiriler Kitabı, 492-496.

Baki, A. ve Bell, A. (1997). Ortä̈ğretim matematik öğretimi. Ankara: YÖK.

Brooks, J.G. ve Brooks, M.G. (1993).In Search of Undestanding: The casr for constructivist classrooms. Alexandria, VA: Association for Supervision and Curriculum Development.

Brown, D. G. (2001). Hybrid courses are best. Syllabus: New Dimensions in Education Technology. http://campustechnology.com/articles/38645/ (Erişim Tarihi:07.02.2012)

Dabbagh, N., Banan-Ritland, B. (2005). Online Learning concepts, strategies and applications. Upper Saddle Rir, New Jersey: Merrill Prentice Hall.

Driscoll, M. (2002). Blended learning: Let's get beyond the hype, E-Learning.3(3) 5454.http://www3.ibm.com/software/mindspan/distlrng.nsf/89297bbbe911d278852567 4c00675635/20630ec43b8dbb4985256b810060561e/\$FILE/Blended\%20Learning\%20F eb\%202002.pdf (Erişim Tarihi: 17.10.2011)

Eunjoo, O.H. (2006). Current practices in blended instruction, Yayımlanmamış Doktora Tezi, Knoxville:The University of Tennessee.

Gray, A., (1997). Contructivist teaching and learning. SSTA Research Centre Report.

Hanley, S. (1994). On constructivism. Maryland for teacher preperation, College Park, MD. http://www.towson.edu/csme/metp/Essays/Constructivism.txt (Erişim Tarihi: 29.09.2011)

Herrington, J., ve Standen, P. (2000). Moving from an instructivist to a constructivist multimedia learning environment. Journal of Educational Multimedia and Hypermedia, 9(3), 195 - 205.

Jonassen, D. (1991). Evaluating constructivist learning. Educational Technology, 36(9) 28-33.

Jonassen, D. (1999). Designing constructivist learning environments. In Ed. C. M. Reigeluth (Ed.) Instructional-Design Theories and Models. (2) 215-239). London:Lawrance Erlbaum Associates Publishers. 
Jonassen, D. H., Peck, K. L., ve Wilson, B. G. (1999). Learning with technology: A constructive perspective. New York: Prentice-Hall Inc.

Kaptan, F. ve Korkmaz, H. (2001). Fen eğitiminde probleme dayalı öğrenme yaklaşımı. Hacettepe Üniversitesi Eğitim Fakültesi Dergisi, (20)191-192.

Mantyla, K. (2001). Blending e-learning. Alexandria, VA: ASTD.

Osguthorpe, R. T., Graham, C. R. (2003). Blended learning systems: Definitions and directions. Quarterly Review of Distance Education, 4(3). 227-233.

Sever, S., Kaya, Z. ve Aslan, C. M. (2006). Etkinliklerle Türkçe öğretimi. İstanbul: Morpa Yayınları.

Singh, H. (2002). Achieving Success with blended learning, Centra White Paper. http://www.centra.com (Erişim Tarihi: 12.10.2011).

So, W. M. (2002). Constructivist teaching in primary science. Asia Pasific Forum On Sicience Learning and Teaching, 3 (1).

Şahin, A. (2001). İlköğretim 6. sınıf öğrencilerinin dinleme becerisi farkındalıklarının sosyo - ekonomik düzeye göre incelenmesi. Çankırı Karatekin Üniversitesi Sosyal Bilimler Enstitüsü Dergisi, 2(1): 178-188.

Ünsal, H. (2007). Harmanlanmış ögrenme etkinliğinin çoklu düzeyde değerlendirilmesi, Yayımlanmamış Doktora Tezi, Gazi Üniversitesi, Eğitim Bilimleri Enstitüsü, Ankara.

Wu, J., Tennyson, R.D., \& Hsia, T. (2010). A study of student satisfaction in a blended e-learning system environment. Computers \& Education, 55, 155-164.

Yaşar, Ş. (1998). Yapısalcı kuram ve öğrenme-öğretme süreci. Anadolu Üniversitesi Eğitim Fakültesi Dergisi. Sayı:8.

Young, J. R. (2002). Hybrid teaching seeks to end the divide between traditional and online. Chronicle of Higher Education, http://chronicle.com/free/v48/i28/28a03301.htm (Erişim Tarihi: 24.01.2012) 